\title{
Effect of Plant Population and Distribution on Yields of Plantains ${ }^{1}$
}

\author{
Ruben Caro Costas ${ }^{2}$
}

\section{INTRODUCTION}

Although plantains (Musa paradisiaca L.), a cooking banana, are a staple in the diet of millions throughout the Humid Tropics, information on their management requirements is limited.

In Puerto Rico, Vicente-Chandler and Figarella $a^{3}$ found that just as high yields of plantains were produced by planting in an undisturbed, as in a thoroughly tilled oxisol (Catalina clay). Yields increased from 10,926 to 19,100 pounds per acre when population was increased from 500 to 800 plants per acre in rows 10 feet apart. In this experiment, plantains responded to the application of 200 pounds of nitrogen and of $\mathrm{P}_{2} \mathrm{O}_{5}$ per acre, but did not respond to lime, magnesium, or potassium applications. Caro, Abruña, and Vicente-Chandler, ${ }^{4}$ on the other hand, found that when all other nutrients were supplied in abundance, plantains growing on a Cialitos clay (an ultisol) responded strongly to the application either of 200 pounds of nitrogen, 200 pounds of $\mathrm{P}_{2} \mathrm{O}_{5}, 400$ pounds of potassium, or 100 pounds of magnesium per acre.

The experiment described in this paper was undertaken to determine the effect of plant population and distribution on yields of intensively managed plantains in the Humid Region of Puerto Rico.

\section{MATERIALS AND METHODS}

The experiment was carried out at Orocovis with a mean annual temperature of about $75^{\circ} \mathrm{F}$., and a seasonal variation of $10^{\circ} \mathrm{F}$. Rainfall was fairly well distributed and averaged 63 inches annually. The soil is Cialitos clay, an ultisol, containing about 4.5-percent organic matter in the surface

1 This paper covers work carried out cooperatively between the Soil and Water Conservation Research Division, Agricultural Research Service, USI)A, and the Agricultural Experiment Station, Mayagüez Campus, the University of Puerto Rico, Río Piedras, P.R.

2 Agronomist, cooperative between the Agricultural Experiment station of the University of Puerto Rico and the Soil and Water Conservation Research Jivision, Agricultural Research Service, USI)A, respectively, stationed at Rio Piedras, P.IR.

${ }^{3}$ Vicente-Chandler, J., and Figarella, J., Experiments on plantain production with conservation in the Mountain Region of Puerto Rico, J. Agr. Univ. P.R. 46 (3): 226-36, 1962.

4 Caro-Costas, R., Abruña, F., and Vicente-Chandler, J., Response to fertilization of Strip-Cultivated plantains growing on a steep Latosol in the IIumid Region of Puerto Rico, J. Agr. Univ. P.R. 48 (4): 312-7, 1964. 
6 inches. Bulk density is 1.05 , and cation-exchange capacity 15.5 meq., with 8.9 meq. of exchangeable bases per $100 \mathrm{~g}$. of soil.

Corms of the Maricongo variety of plantains used as seed were cleaned and immersed in boiling water for 1 minute to kill nematodes. The planting holes and surrounding soil were sprayed with aldrin ${ }^{5}$ solution before planting. The plants were sprayed every 4 weeks with oil, starting at 8 months, to control leaf spot. Planting was in November 1964 and harvesting was was completed in July 1966. Growth of weeds was controlled by handweeding and applying 3 pounds per acre of Simazine at 3 months and repeating the Simazine application at 6 months, followed by hand-weeding as required.

Four tons per acre of calcitic limestone were broadcast before planting. A total of 300 pounds of nitrogen from ammonium sulfate, 200 pounds of

TABLE 1.-Efect of spacing and population on yields of intensively managed plantains

\begin{tabular}{c|c|c|c|c|c|c}
\hline $\begin{array}{c}\text { Treatment } \\
\text { No. }\end{array}$ & $\begin{array}{c}\text { Planting } \\
\text { distance }\end{array}$ & $\begin{array}{c}\text { Plants } \\
\text { per acre }\end{array}$ & $\begin{array}{c}\text { Bunches } \\
\text { harvested }\end{array}$ & $\begin{array}{c}\text { Fruits } \\
\text { per acre }\end{array}$ & $\begin{array}{c}\text { Fruits } \\
\text { per bunch }\end{array}$ & $\begin{array}{c}\text { Individual } \\
\text { fruit } \\
\text { weight }\end{array}$ \\
\hline & Feet & Number & Number & Number & Number & Pounds \\
1 & $10 \times 6$ & 725 & 546 & 21,950 & 40.2 & 0.72 \\
2 & $10 \times 4$ & 1,090 & 783 & 31,000 & 39.6 & .71 \\
3 & $10 \times 3$ & 1,450 & 855 & 29,840 & 34.9 & .73 \\
4 & $5 \times 6$ & 1,450 & 965 & 39,080 & 40.5 & .70 \\
\hline
\end{tabular}

$\mathrm{P}_{2} \mathrm{O}_{5}$ from 20-percent superphosphate, and 600 pounds of potassium from potassium chloride were applied per acre in three equal applications 1,4 , and 8 months after planting. Sixty pounds of magnesium per acre were applied as magnesium sulfate 4 months after planting.

Individual plots were $20 \times 25$ feet, with 8 to 16 plants per plot depending on the planting distance. Rows ran east-west. Treatments shown in Table 1 were replicated 5 times in a randomized block design. The plantains were harvested as they matured.

\section{RESULTS AND DISCUSSION}

Table 1 shows that, with 10 -foot rows, plantain yields increased from 21,950 to 31,000 fruits per acre when population was increased from 725 to 1,090 plants per acre. Planting 1,450 plants per acre did not further increase yields with 10 -foot rows, but planting 1,450 plants per acre approximately

5 Trade names used to provide specific information; this does not imply endorsement or recommendation. 
on the square ( 5 feet $\times 6$ feet) increased yields to 39,080 fruits per acre (figure 1).

Bunch and fruit size were not significantly affected by the population levels tested although bunches tended to be smaller with the $10-\times 3$-feet planting distance.

Weeding costs decreased with increasing populations, but sucker growth

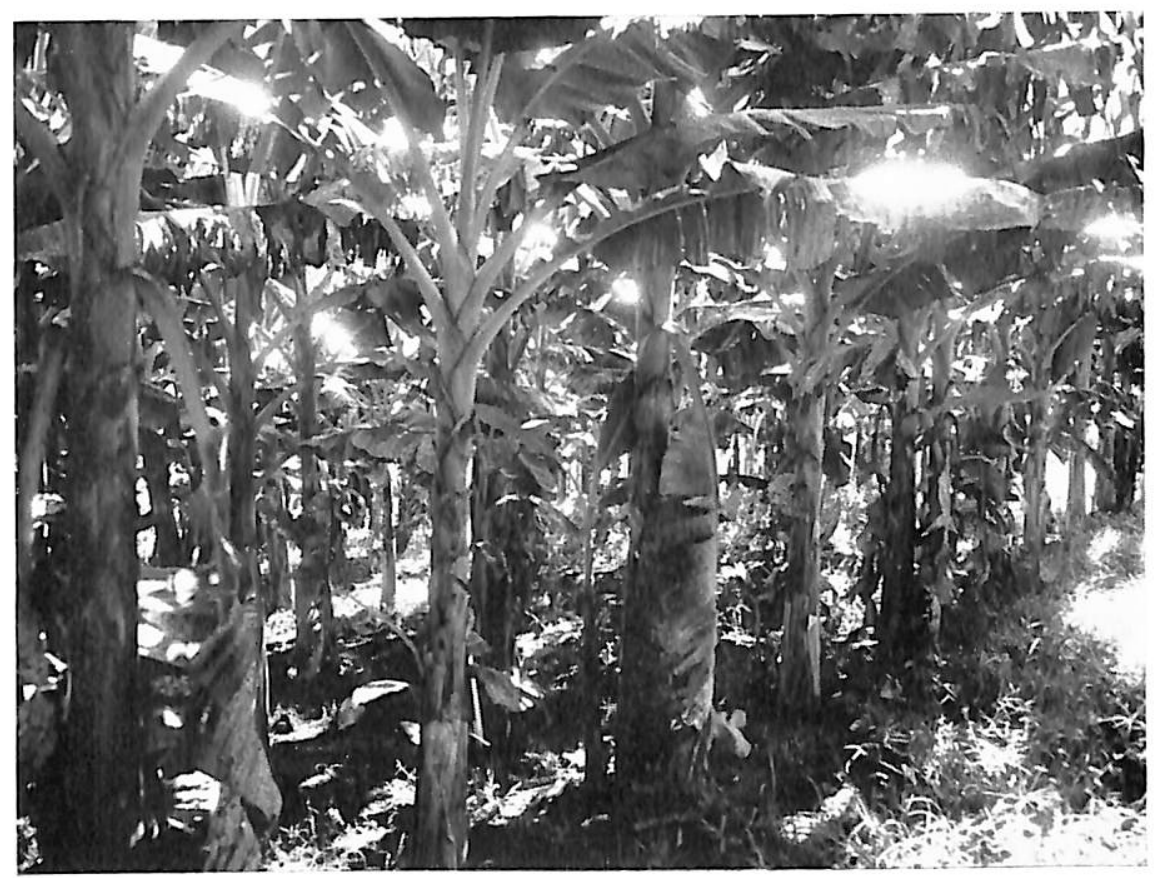

FIG. 1.-Plantains planted at $5 \times 6$ feet $(1,450$ plants per acre $)$ yielded 39,000 high-quality plantains per acre, almost twice as much as with the conventional 700 plants per acre.

was delayed in high populations until harvesting was well underway. This resulted in a more uniform, if delayed, growth of the rattoon crop.

Strong winds and nematode infestations resulted in heavy loss of plants by toppling shortly before or after fruiting, heaviest losses (38 percent) occurring with 1,450 plants per acre. At this late stage the toppled plants had probably exerted most of their competitive effect on the remaining ones without decreasing bunch or fruit size. Thus, even higher yields could be expected with 1,450 plants per acre if losses from nematode and wind damage could be reduced.

These data show that a rate of up to 1,450 plantains per acre, planted 
approximately on the square, should be used in Puerto Rico. Yields obtained with 1,450 plants per acre in this experiment were almost twice as high as those obtained with the usual 700 plants per acre and bunch and fruit size were unaffected.

\section{SUMMARY}

With 10-foot rows, plantain yields increased from 21,950 to 31,000 fruits per acre when population was increased from 725 to 1,090 plants per acre. Planting 1,450 plants per acre with 10 -foot rows did not further increase yields, but planting 1,450 plants per acre, approximately on the square, $(5 \mathrm{ft}$. $\times 6 \mathrm{ft}$.) increased yields to 39,080 fruits per acre. Bunch and fruit size were not affected by the population levels tested. Yields obtained with 1.450 plants per acre were about twice those obtained with the 700 plants per acre commonly used in Puerto Rico.

Strong winds and nematode infestations resulted in heavy loss of plants by toppling shortly before or after fruiting, particularly with 1,450 plants per acre. Weeding costs decreased with increasing population and sucker growth was delayed in high populations until harvesting was well underway.

\section{RESUMEN}

La producción de plátanos por cuerda aumentó de 21,950 a 31,000 frutas al sembrarse 1,090 en vez de 725 plantas, en hileras de 10 pies de separación. La siembra de 1,450 plantas por cuerda no reflejó aumento adicional en la producción en hileras igualmente distanciadas, pero sí produjo 39,080 frutas por cuerda cuando las plantas se sembraron a 5 pies $\times 6$ pies. El tamaño del racimo y el de las frutas individuales no sufrió cambio alguno al variar el número de plantas por cuerda. La producción casi se duplicó al sembrarse 1,450 plantas por cuerda en vez de 700 , que es lo corriente.

El viento y los nemátodos causaron considerables pérdidas al caerse un crecido número de plantas ya con racimos o próximas a fructificar, especialmente en las parcelas con 1,450 plantas por cuerda. Los costos de desyerbo aminoraron al aumentarse el número de plantas por cuerda y se retardó el crecimiento de hijos en las parcelas más densamente pobladas hasta después de bien comenzada la cosecha. 